well'; if we say that to Christ, He will take the die into His own hand, and $\mathrm{He}$ will stamp our life for us.

And what do you think the impression will be? Why, it will be just a portrait of Himself. In olden days the kings had on their royal seals their own portraits, and when they stamped anything with the royal seal every one knew it belonged to the king, for they saw his image there. So with Christ's seal. Others looking on us, and seeing the impression on our clay, will say, 'They too belong to Christ.'

\title{
Diberning the d5ody.
}

\author{
By the Rev. James Moffatt, D.D., D.Litt., Professor of Church History in the \\ United Free Church College, Glasgow.
}

What does Paul mean by this elliptical phrase in his description of the Christian's relation to the Lord's Supper? The passage ( $\mathrm{I}$ Co $\mathrm{II}^{29}$ ) runs thus: 'For he who eats and drinks without a proper sense of the body ( $\mu \grave{\eta} \delta\llcorner a \kappa p i v \omega \nu$ tò $\sigma \hat{\omega} \mu a)$, eats and drinks to his own condemnation.' It falls to be interpreted in the light of the preceding discussion upon the meaning of the Lord's Supper, and the variety of opinions with regard to Io ${ }^{16 f}$. I I ${ }^{17 f}$, is reflected in the variety of interpretations assigned to $\mathrm{II}^{20}$. The problem has been again opened by Professor Morgan in his recent original work on The Religion and Theology of Paul (p. 224). It is of vital importance for the understanding of Paul's attitude towards the sacrament; but, before referring to Professor Morgan's theory, we had better survey the rival interpretations of the phrase.

They fall into two groups, familiar to students of the Epistle and its criticism. (i.) The most obvious is, 'not discriminating between the body' of the Lord, as represented by the consecrated bread, and the ordinary bread at the church Supper. The greedy, selfish person who snatches at the

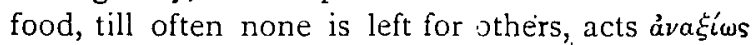
$(v .27$; he fails to see that there is any real difference between the bread and wine of this Supper and the provisions at an ordinary meal. Such behaviour, as Paul has said, 'makes it impossible for you to

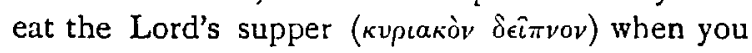
hold your gatherings' $\left(v^{20}\right)$. It is an act of irreverence, which renders the perpetrator guilty of sacrilege, in the ancient sense of the term, namely, guilty of violating a sacred order which avenges itself upon the offender. He has to answer for a

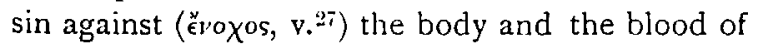

the Lord, represented by the bread and wine; as he eats and drinks, in his profane, careless way, he involves himself in a condemnation or $\kappa p i ́ \mu \alpha\left(v .{ }^{29}\right)$, which comes immediately into operation $\left(v{ }^{30}\right)$.

This view seems to tally with the situation at Corinth. From Paul's language ( $\mathrm{I}^{17 \mathrm{f}}$ ) we gather that the local church was in the habit of gathering for an evening love-feast or charity-supper, at which the Eucharist was also celebrated. This love-feast was the Christian equivalent for the supper of the guilds; it was not a 'sacrament' in the modern sense of the term, i.e. a gathering at which the eating is only a form, but a real supper ${ }^{1}$ of the church, the food being provided by the wealthier members in the main. Only, at Corinth some were in the habit of hurrying to eat what they had brought, without waiting for the poor slaves or tradesmen who could not arrive till their day's task was done. This indecent behaviour was a disgrace to the church. It showed the cliques and sets within the church; it brought out invidious distinctions of social position, which were entirely out of keeping with the unity of the Church as the Lord's Body. Also, it left the late-comers with little or nothing to eat at all. Finally, it betrayed a gross disrespect for the religious aspect of the loaf and the cup. According to the interpretation under review, it is this last point which is pressed home by the apostle in $\mathrm{v}^{29}$. No one who had a proper sense of what the bread and the wine at the love-feast of the Lord meant, would behave so greedily that some of his fellow-members would have to go without any of the food, while

1 'Un vrai souper, oì chacun mangeait selon sa faim, seulement avec une haute intention mystique' (Renan, S. Paul, p. 265). 
he himself might actually be drunk by partaking too freely of the wine $\left(v^{21}\right) .{ }^{1}$ If you want to give dinners to each other or to satisfy your appetites merely, do that at home $\left(\mathrm{v}^{22}\right)$; there the bread and the wine are not what they are at the кvplakò $\delta \epsilon \hat{i} \pi v o v$.

(ii.) Another interpretation is: 'Not taking a right view of the body' (as represented in the bread), i.e. failing to appreciate the full and deep significance of the bread as a religious symbol or sign. Instead of blaming the Christians at Corinth for failing to draw a difference between the efficacy of the sacramental loaf and an ordinary loaf, the apostle is supposed to warn them against an inadequate appreciation of the sacramental loaf itself. Apparently this was the view of Chrysostom

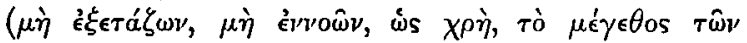

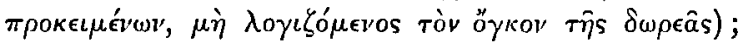
the man 'does not inquire into, does not understand, as he should, the greatness of what is put before him, does not appreciate the importance of the free gift.'

But where did this lack of spiritual apprehension lie? The interpretation branches into two lines.

(a) According to some, especially Dean Stanley, for example, by 'the Body' is meant the unity of the Christian Church as the Lord's Body, a unity which is broken and disparaged by the selfish conduct of these Corinthians. In Io ${ }^{16 f}$, after asking, 'The cup of blessing, which we bless, is that not participating in the blood of Christ? the bread we break, is that not participating in the body of Christ?'-the apostle at once adds, in a parenthesis 'for many as we are, we are one bread, one body, since we all partake of the one bread.' This instinctive comment shows how deeply the idea of the unity of the Church, as prefigured in the Eucharist, had penetrated the mind of Paul; it shows also that, after speaking of the bread and the cup, he could sum up the particular significance of the Supper as 'the bread,' and correlate that with 'the body.' This figurative or mystical sense

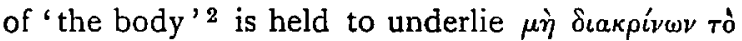

1 'One took the holy bread to assuage his hunger, another drank the wine when he had already confused his brains by drinking, making no distinction between this and any other bread and wine" (Hausrath, History of N.T. Times, iv. 27).

"As in $12^{12 .} 13$ ("by one Spirit we have all been baptized into one body'), $12^{27}$ ('you are Christ's body, and severally members of it'), etc. Weizsäcker (Apostolic Age, ii. 282), reading $\tau \dot{\partial} \dot{v} \pi \dot{\epsilon} \rho \dot{v} \mu \hat{\omega} \nu$ in $\mathrm{II}^{24}$, refused to see any allusion to Christ's death except in the cup; the bread was the symbol $\sigma \hat{\omega} \mu a$ in $\mathrm{II}^{29}$. What Paul has been censuring (v. ${ }^{\text {18f. }}$ ) is the selfishness and lack of consideration at the church gatherings, the display of party-spirit and unbrotherly greed. What he desires is a due appreciation, on the part of each worshipper, of what membership in 'the body' involves. To partake of the Supper properly, one must recognize it as imposing obligations of brotherly love and fellowship. To eat and drink 'worthily' ( $(\dot{a} \xi i \omega s)$ is to do so recognizing that they are 'participating in the body and the blood of the Lord' (kouvwroi

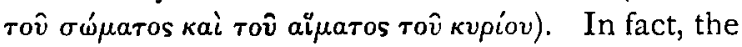
Body (

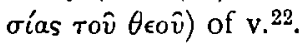

The stress laid by this interpretation ${ }^{3}$ upon the unity of the Church corresponds to the introductory paragraph (vv. ${ }^{19-22}$ ) and to the conclusion (vv. ${ }^{38 .}{ }^{34}$ ), in which Paul reiterates his protest against the selfishness which reduced the supper to a private meal, instead of a common gathering for fellowship. The stress of the other $(b)^{\prime}$ line falls upon the use of $\sigma \hat{\omega} \mu \alpha$ in the special account of $v .^{23-2 \tau}$, as the sacrificial body of the Lord in connexion with the bread or loaf of the Eucharist. In $\mu \grave{\eta} \delta\llcorner a \kappa \rho i z \omega \nu$ rò $\sigma \tilde{\omega} \mu \alpha$, Paul censures the indifference of the Corinthian Church, or of some of its members, to the true meaning of the bread $\left(\mathrm{v}^{24}{ }^{24}\right.$ ' this is my

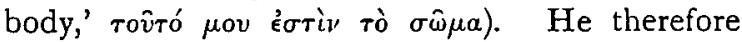
recalls them to the interpretation of the rite which he had originally given them $\left(\mathrm{v} .{ }^{23}\right.$, "which also I

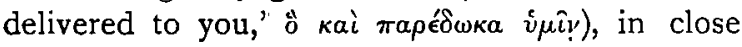
connexion with the death of Christ. At Corinth he had emphasized this truth, set it vividly before their conscience and imagination, 'proclaiming' it

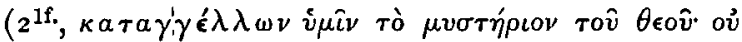

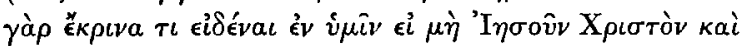

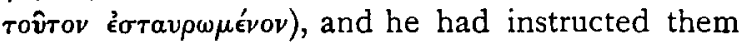
on the meaning of the Supper from the same point of view as a rite in which they 'proclaimed' the

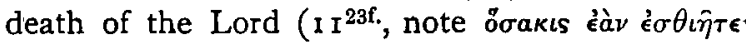

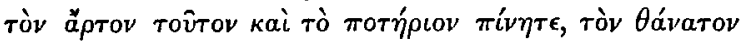

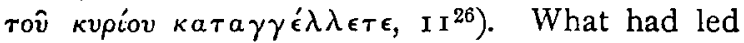
the Corinthians to ignore or undervalue this inter-

of Christ's presence with the Church, for Paul, though the Synoptic formula, 'This is my body,' meant 'the body of Christ as the unity of the church.' This is doubly wrong.

${ }^{3}$ It tallies with the prayer over the bread in the Didachê $\left(9^{4}\right)$ : 'As this broken bread was scattered upon the hills and was brought together and made one, so let thy church be gathered together from the ends of the earth into thy kingdom '-although the reference is eschatological, and slightly fanciful. 
pretation, we can only guess. Was it a mere irreverent habit? Or had they begun to make the sacrificial meal, as in the light of contemporary cult-feasts, a means of participation in the life of the Risen Lord by eating and drinking ( $\left.10^{16 f}\right)$ ? Probably the former. But in any case they required to be brought back to the solemn truth that what they did was in remembrance of Christ's death, and that what they ought to do was to appropriate His death gratefully and eagerly.

Professor Morgan's view agrees with this. He finds the determining passage in 'This do in remembrance of me. For as often as ye eat this bread, and drink the cup, ye proclaim the Lord's death till he come' (vv.25. 26), words which Paul added to the primitive tradition, and which form the index to his own conception. 'A memorial of Christ's sacrificial death, a means of proclaiming it - that and that alone is what the Supper signifies for Paul. And if we are right in supposing that he finds the Corinthian observance not merely disfigured by moral abuses, but also defective in the matter of knowledge, may we not say that what he misses in it is precisely the vital thing-a recognition of Christ's sacrificial death (cf. I Co $2^{\text {If }}$ ). With all their striving after mystic knowledge and mystic union, the Corinthian Christians failed to "discern" in the Supper the Lord's broken body and shed blood. They were guilty of the body and blood of the Lord in the sense that they ignored and flouted the significance of these divine realities.' This is true to the reiterated mention of

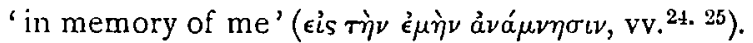
The Supper was not to Paul a commemorative festival, as in some Greek guild a banquet might be held in annual memory of a departed member.

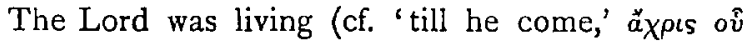
É $\left.\lambda \theta \eta, v^{26}\right)$. He was present as 'Lord ' (Kúpıos) at

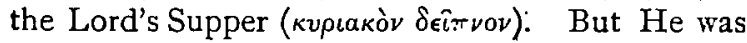
not present at it as $\mathrm{He}$ had been at the Supper 'on the night when he was betrayed.' That Supper was a prophetic anticipation of the death which the Christian Eucharist commemorates as the basis of living fellowship with God. Consequently to sin against 'the body and the blood of the Lord' is to $\sin$ against the sacrificial death, to be indifferent to what the Supper means for all true disciples. It has nothing to do with any failure to recognize in the actual loaf either a symbol of the divine reality or a vehicle for, the transmission of the Lord's life into the participant who digests his morsel. ${ }^{1}$

One of the crucial difficulties in deciding which of the various interpretations is correct, is not linguistic but historical. $\Delta$ iàкpí̀ $\omega \nu$ may mean 'appreciating' in $v^{29}$, 'taking a right view of'although it does not follow that Paul used so flexible a term in exactly the same sense both in $\mathrm{II}^{29}$ and in $\mathrm{II}^{31}$ (if we only judged our lives truly, we would not come under the Lord's

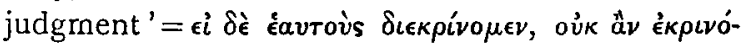
$\mu \epsilon \theta a)$; he might well be playing on the different meanings of the term, and in $4^{7}$ he had certainly used the verb to mean 'discriminate' or 'single out' ("who maketh thee to differ, who singles you

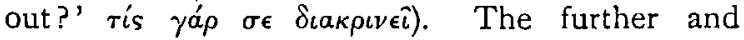
harder problem is, What was the precise situation to which he was referring? How was the Lord's Supper connected with the love-feast? We do not even know whether it was celebrated at the beginning or at the end of the common meal. The members at Corinth assembled, we may

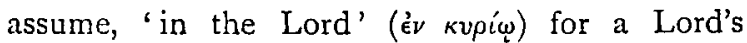

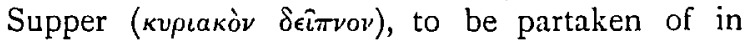
presence of the Lord (Kúpıs) as their invisible Host and Head, with whom, as they ate and drank, they were in vital union; the holy kiss and the breaking of bread together were simple, realistic expressions of their corporate unity; and a solemn blessing, invoking and recognizing the presence of the Kripos, opened the meal. But was there a special loaf, was there a special cup, set apart for the Lord's Supper, during the course of the meal? Or were the entire materials of the simple feast regarded as consecrated by the initial blessing, so that the Church Supper corresponded to the 'breaking of bread' elsewhere, e.g. in the Church at Jerusalem? If the latter view is taken, the first interpretation (i.) becomes less probable than the second (ii.).

What tells further against (i.) is the probability that if such had been Paul's meaning, he would

1 Professor Morgan's trenchant refutation of this hypothesis (pp. 2 I $_{3}$ f., 224 f.), which is enjoying a passing vogue in some quarters, agrees with Schweitzer and J. Réville in brushing aside the attempt to interpret $\mathrm{II}^{20}$ in the light of $\mathrm{IO}^{16}$, as if 'the body' were the divine nature identified with the loaf of which the worshippers ate. In Dr. P. T. Forsyth's Church and the Sacraments (p. I52), Professor H. T. Andrews pleads that 'honest exegesis' obliges us to adopt some such interpretation. 'Honest' is hardly the adequate epithet to be ear-marked for exegesis of this kind. 
have written: 'For he who eats and drinks without discerning or discriminating the body and the blood, eats and drinks to his own condemnation.' In short, this interpretation is not adequate to the

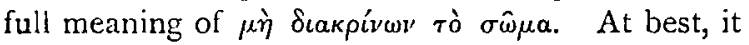
suggests a starting-point for that meaning, and the

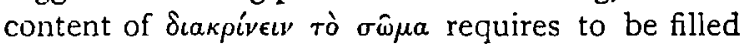
out from the context, especially from what has

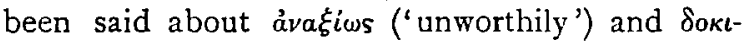

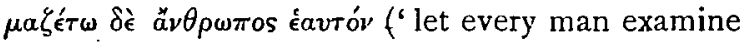
himself' $\left.=v^{\prime}{ }^{31}\right)$. Now these phrases suit (ii.) ex-

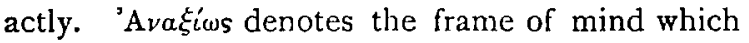
does not trouble to put itself into line with the object of Christ in the Supper. To partake

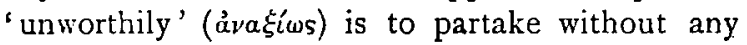
due recollection or perception of the death and passion which the rite commemorates. This is of course irreverent; it is to eat the bread and drink the wine as if they meant nothing special. But the irreverence consists in the irrelevance of the communicant to the feast. 'Ava $\xi^{\prime}$ 'ws is 'carelessly,' 'heedlessly,' not 'unworthily.' And this is what the next phrase about 'testing oneself' implies. 'Let a man test himself; then he can eat from the loaf and drink from the cup.' Let him make sure that he knows what he is doing, let him realize his position, as one for whom the Lord died, as a member of the community, of the Body of Christ. The best preparation for partaking in the Supper, Paul implies, is a realization of the infinite obligations we are under to Christ and to one another.

I say, 'to Christ and to one another,' ' because, although the second (ii.) interpretation is preferable, it is quite unnecessary to narrow the meaning

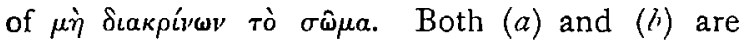
required to round off its significance. On the one hand, $\tau$ ò $\sigma \hat{\omega} \mu a$ must retain some of the suggestiveness of vv. ${ }^{23-28}$. 'The Lord Jesus took a loaf . . . saying, This loaf means my body ( $\tau$ ò $\sigma \hat{\omega} \mu a$ ) broken for you. .... As often as you eat this loaf ... you proclaim the Lord's death ... he who eats the loaf carelessly ... will have to answer for a sin against the body (rov̂ $\sigma \dot{\omega} \mu a \tau o s$ ) of the Lord.' It is to this sacrificial significance of the Supper

${ }^{1}$ Calvin (on I Co $\mathrm{II}^{29}$ ) recognizes this explicitly. "Vides expeditissinam methodum. Si rite vis uti Christi beneficio, fidem afferas et poenitentiam : in his ergo duobus constitit examen, ut venias bene preparatus. Sub poenitentia charitatem includo: nam qui sibi renuntiare didicit, ut se Christo eiusque obsequio addicat, ille etiam procul dubio unitatem a Christo commendatam ex animo colet.' that Paul is recalling the Corinthians. When he

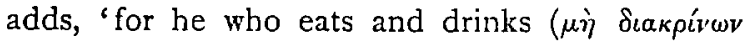

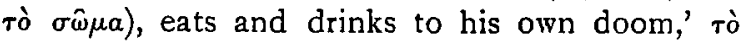
$\sigma \hat{\omega} \mu \alpha$ is a compact expression for the foregoing 'body and blood'; to eat the loaf without reflecting what it means in the Eucharist is fatal, that is Paul's point. If there is not a blessing in it, there is a curse, and the blessing depends upon the reverent appreciation of the Supper as commemorating the Death.

Or rather, it is Paul's primary point, we should say. As we have seen, the turn of thought and expression in $10^{16.1 \tau}$ proves that rò $\sigma \hat{\omega} \mu a$ for Paul in this connexion carried the further sense of unity with the Lord. When he speaks of the Church participating in the body of Christ, as the loaf is broken and eaten at the Eucharist, he can instantly think of the Church itself as the Body of Christ. The mystical, imaginative expression calls up both truths together. For the object and end of Christ's sacrificial death is reconciliation to one another, through reconciliation to God; the essential meaning of the Eucharist, as of the sacrifice which it represents, is in one aspect the common fellowship of those who are 'in the Lord' $\left(\dot{\epsilon} v \kappa v \rho^{\prime} \omega\right)$. The love-feast, with which the Supper was conjoined at Corinth, was intended to express the common life of Christians as the Body of the Lord, and this is close to Paul's mind in I Co $\mathrm{II}^{17-34}$. He begins with it and ends with it. What he denounced as utterly incompatible with any proper observance of a 'Lord's' Supper (кupıakò $\delta \in i \pi \nu 0 v)$ was the selfish individualism which the

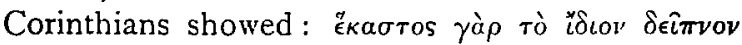

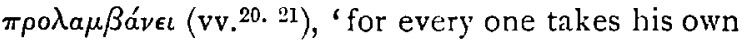
supper.' He is about to deal with this in chap. I2, where the conception of the Body and its members is developed, in order to prove the weakness and absurdity of this $\tilde{\epsilon} \kappa a \sigma \tau o s$ individualism. But already, in discussing the Supper, he has it in mind. And when he closes by telling the Corinthians to wait for one another at their church gatherings, instead of disregarding their fellowmembers ( $\left.v{ }^{33 .}{ }^{34}\right)$, he is reiterating a counsel which he had already suggested in $\mu \grave{\eta} \delta\left\llcorner\alpha \kappa i^{\prime} \nu \omega \nu\right.$ rò $\sigma \hat{\omega} \mu \alpha$.

It is therefore unnecessary to confine the mean-

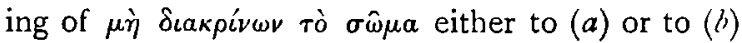
of the second interpretation. Neither in view of Io ${ }^{16 f}$ nor in the light of I I $^{17 f}$ can we say, with Professor Morgan (op. cit. p. 226), that the Lord's Supper meant 'a memorial of Christ's sacrificial 
death-that and that alone' to Paul, still less that 'the conception of the rite as binding believers into a fellowship with one another never emerges' (p. 22I). Mr. Srawley is right in arguing that, while the primary reference of $\tau \dot{o} \sigma \bar{\omega} \mu a$ in $v^{29}$ is to the 'body' (cf. v. ${ }^{24}$ ), 'it is possible'-I would put it more strongly, it is highly probable-' that he has in view the more inclusive sense of "body" referred to in I Co I ${ }^{16.17}$. By his selfish action the richer brother failed to recognize that the sacred meal was a fellowship of believers with Christ and with one another. It was the sacrament of their incorporation in Christ. The abuses at Corinth turned it into a private meal' (Encyclopadia of Religion and Ethics, v. $543^{b}$ ). Hence the deliberate choice of $\tau \grave{o} \sigma \hat{\omega} \mu a$ in I I ${ }^{29}$, not simply because it summed up concisely the idea of 'the body and the blood' (the body suffering death by the shedding of blood), but also because it called up the idea of the Body of Christ as the Church.

\section{Eiterature.}

\section{THE CRITIQUE OF PURE REASON.}

Dr. Norman Kemp Smith, McCosh Professor of Philosophy in Princeton University, has written $A$ Commentary to Kant's 'Critique of Pure Reason' (Macmillan; 2 rs. net). In theology a distinction is made between a Commentary and an Exposition, the former being an explanation of the author's words and phrases, with only an incidental reference to his thought; the latter being an explanation of his thought, with only an occasional reference to his phraseology. Dr. Kemp Smith's Commentary is an Exposition.

Few books that have been written require a Commentary (we keep Dr. Kemp Smith's word) more than Kant's Critique of Pure Reason. For it is not merely defective in clearness or popularity of expression. 'That,' as Professor Kemp Smith says, ' is a common failing of metaphysical treatises, especially when they are in the German language, and might pass without special remark. What is much more serious is that Kant flatly contradicts himself in almost every chapter, and that there is hardly a technical term which is not employed by him in a variety of different and conflicting senses. As a writer, he is the least exact of all the great thinkers.'

What is the explanation? The explanation is that the Critique was written in portions during a period of eight years, and at the end of that period $\left(x_{7} 80\right)$ the portions were run together into one treatise within the space of five months. Even the piecing together of these manuscripts was done under such disadvantages as made coherence an impossibility. For Kant objected to the sacrifice of an argument if once it had been committed to writing. "If it could be inserted, no matter at what cost of repetition, or even confusion, he insisted upon its insertion.'

Here is room enough for inconsistency. But there is more. Kant's supreme merit as a philosophical thinker, especially as shown in the first Critique, is his open-minded recognition of the complexity of his problems, and of the many difficulties which lie in the way of any solution which he is himself able to propound. Kant's method of working seems to have consisted in alternating between the various possible solutions, devtloping each in turn, in the hope that some midway position, which would share in the merits of all, might finally disclose itself. When, as frequently happened, such a midway solution could not be found, he developed his thought along the parallel lines of the alternative views.

Last of all comes the fact of more than one edition. Of the result Dr. Kemp Smith gives a striking example when he is dealing with Kant's refutation of idealism. 'The new refutation of idealism in the second edition differs from that given in the fourth Paralogism of the first edition, not only in method of argument, but also in the nature of the conclusion which it seems to establish. Indeed it proves the direct opposite of what is asserted in the first edition. The earlier proof sought to show that, as regards immediacy of apprehension and subjectivity of existence, outer appearances stand on the same level as do our inner experiences. The proof of the second edition, on the other hand, argues that though outer appearances are immediately apprehended, 